\title{
Effects of prescribed burning on carbon accumulation in two paired vegetation sites in subtropical China
}

\author{
Yuanqi Chen ${ }^{1,2,3}$, Jianbo $\mathrm{CaO}^{2,4}$, Lixia Zhou ${ }^{2}$, Feng Li, ${ }^{2,4}$ and Shenglei $\mathrm{Fu}^{5 *}$
}

\begin{abstract}
Background: Prescribed burning is a common practice of site preparation before afforestation in subtropical forests. However, the effects of prescribed burning on carbon (C) dynamics of an ecosystem are poorly understood. Therefore, a Eucalyptus urophylla plantation (EU) and a naturally recovered shrubland (NS), each treated with prescribed burning and no burning were examined in subtropical China.

Methods: Biomass of trees and shrubs in the 1st, 3nd, 4th, and 6th year after treatments were estimated by quadrat survey and allometric equations. Biomass of herbs and forest floors were estimated by harvest method. Plant biomass $C$ storage was calculated by plant biomass multiplying by its $C$ concentration. Soil organic $C$ (SOC) storage in the 6th year after treatments was estimated by SOC concentration multiplying by soil bulk density and soil volumes.

Results: Tree biomass C storage was significantly higher in the burned EU (BEU) than in the unburned EU (UEU) in the 1st year after treatments, yet the difference decreased over time. Conversely, tree biomass $C$ storage was lower in the burned NS (BNS) than in the unburned NS (UNS), although the difference was not significant. However, in the 6th year after treatments, the total plant biomass C storage was $14.56 \%$ higher in the BEU than that in the UEU, and $59.93 \%$ higher in the BNS than that in the UNS, respectively, although the significant difference was only found between UNS and BNS. In addition, neither SOC storage at 0-20 cm nor ecosystem C storage in either the EU or NS was significantly affected by prescribed burning.

Conclusions: Prescribed burning has little impact on overall $C$ storage of forest ecosystems, we consider that prescribed burning may be an option for forest site preparation regarding plant biomass $C$ accumulation.
\end{abstract}

Keywords: Prescribed fire, Reforestation, Plant biomass carbon, Soil organic carbon, Forest management

\section{Background}

Prescribed burning is used widely as a forest management technique to prepare sites for seeding or planting, reduce fuel loads and control plant disease (Muqaddas et al. 2016). Meanwhile, prescribed burning in forest management can reduce resource competition between target trees and shrubs, improve above and below-ground ecosystem structures and functions, and help maintain the biodiversity and ecological balance of forest ecosystems (Glitzenstein et al. 2012). In addition, prescribed burning

\footnotetext{
* Correspondence: fsl@henu.edu.cn

${ }^{5}$ Key laboratory of Geospatial Technology for the Middle \& Lower Yellow River Regions, Ministry of Education, College of Environment and Planning, Henan University, Kaifeng 475004, China

Full list of author information is available at the end of the article
}

influences soil physical, chemical and biological properties (Certini 2005; Alcañiz et al. 2018), such as soil structure, soil texture, soil organic matter content and soil microbial activity (Granged et al. 2011; Williams et al. 2012; Hu et al. 2016). Thus, prescribed burning could affect carbon (C) accumulation in forest ecosystem. However, the effect of prescribed burning on $\mathrm{C}$ dynamics was inconsistent. For instance, surface fires significantly reduced $C$ sequestration by forests in a short term study, especially causing forest floor $\mathrm{C}$ and nitrogen $(\mathrm{N})$ losses (North and Hurteau 2011). Meanwhile, surface soil $C$ and $N$ were decreased in burned plots (Alcañiz et al. 2016; Pellegrini et al. 2018). 
Conversely, Rau et al. (2009) found that prescribed burning caused only immediate increases in surface soil $\mathrm{C}$ and $\mathrm{N}$ concentration, but over longer periods of time no statistically detectable change occurred. Furthermore, prescribed burning could affect plant biomass $\mathrm{C}$ accumulation through altering soil nutrient availability (Scharenbroch et al. 2012). Therefore, understanding the role of prescribed burning in forest $\mathrm{C}$ dynamics is very important for $\mathrm{C}$ cycling (Fahey et al. 2010; Landry et al. 2015). Previous studies have compared plant biomass, SOC concentration and pyrogenic C concentration pre- and post-fire (Pellegrini et al. 2015; Fultz et al. 2016; Krishnaraj et al. 2016), but total C storage in the forest ecosystem has been less considered. In addition, the effects of prescribed burning on forest $\mathrm{C}$ stocks in different vegetation types remain unclear.

Plantation forest plays a crucial role in alleviating $\mathrm{CO}_{2}$-concentration increases (Marín-Spiotta and Sharma 2013). China has plantations of approximately 69 million hectares, which is approximately one third of the world's plantation area (State Forestry Bureau 2014). Furthermore, more than $60 \%$ of the plantation area in China is distributed in the subtropics (Wang et al. 2010). Eucalyptus, a fast-growing species, is widely planted in southern China and many other countries throughout the world because of its wide adaptability, high productivity, and rapid economic returns (Fischer et al. 2017). Eucalyptus plantations cover 4.50 million hectares in China and represent approximately $34 \%$ of the total plantation area in southern China (China Forestry Database n.d.; China Science Daily 2015). The rotation period of Eucalyptus plantations is approximately 4 to 8 years (Quality and Technology Supervision of Hainan Province, China 2004). Prescribed burning regularly occurs in site preparation for plantation forests or during rotation in subtropical China. Therefore, evaluating the effects of prescribed burning on the $\mathrm{C}$ dynamics of plantation ecosystems is urgently necessary to understand how $\mathrm{C}$ cycling responds to it. Additionally, the vegetation types or restoration treatments could cause different responses to prescribed burning (Shorohova et al. 2008; Wang et al. 2013), so a Eucalyptus plantation and a naturally recovered shrubland with no planted tree were tested in the present study.

We addressed the following two questions: (1) How does prescribed burning affect plant biomass $C$ storage and SOC storage? (2) Do the vegetation types cause the different responses of $\mathrm{C}$ accumulation to prescribed burning? Inventory data from the Heshan National Field Research Station of Forest Ecosystem was used to estimate plant biomass C storage and SOC storage on a Eucalyptus plantation and a naturally recovered shrubland with burning and no burning treatments at the early developmental stages of vegetation.

\section{Methods \\ Site description}

The experiment was conducted at the Gonghe Experimental Site, Heshan National Hilly Land Interdisciplinary Experimental Station $\left(112^{\circ} 50^{\prime}\right.$ E, 22 $34^{\prime}$ N), Chinese Academy of Sciences (CAS). This site is located in Heshan City, Guangdong Province, China. The Gonghe Experimental Site was established in 2005 on hilly land with similar site characteristics, which included 14 forest types (e.g., monoculture, mixed, exotic, or native plantations) or management techniques (burning or clear-cutting) (Chen et al. 2015). This region belongs to typical subtropical monsoon climate. The mean annual temperature was $21.7^{\circ} \mathrm{C}$ and the precipitation was around $1700 \mathrm{~mm} \cdot \mathrm{yr}^{-1}$. The average elevation is $10-80 \mathrm{~m}$, and the soil is an acid Acrisol with a $\mathrm{pH}$ of approximately 4.0.

Prescribed burning was carried out to prepare sites for planting seedlings in March 2005 (Sun et al. 2011, dry weight of the aboveground biomass was less than 15.0 $\mathrm{Mg} \mathrm{ha}^{-1}$ ). The daily air temperature was approximately $16.5^{\circ} \mathrm{C}$, and the precipitation was $109.6 \mathrm{~mm}$ in March 2005. The previous vegetation type was shrubland, and after logging all trees (Pinus elliotti), all vegetation in the experimental site was slashed. Logging residues were left in the unburned plots, but were burned in the burned plots. E. urophylla seedlings were planted at a spacing of $2 \mathrm{~m} \times 3 \mathrm{~m}$ in the plots of Eucalyptus plantations in May 2005. In the plots of naturally recovered shrubland, no seedlings were planted, where the plant communities were recovered naturally after treatments. Two paired vegetation sites (a naturally recovered shrubland vs. a E. urophylla plantation) were selected for this study. Thus, this study included the following four treatments: burned and unburned naturally recovered shrubland (BNS, UNS), and burned and unburned E. urophylla plantation (BEU, UEU). Each treatment plot has three replicates, each with an area of 1 ha. Additionally, all plots were arranged in a completely randomized design. The burned plots are more than $100 \mathrm{~m}$ away from the unburned plots. Understory vegetation in this studied site was highly dominated by the Dicranopteris dichotoma (Sun et al. 2011). The SOC concentration was $9.45 \pm 0.21 \mathrm{mg} \cdot \mathrm{g}^{-1}$, the soil nitrogen concentration was $0.67 \pm 0.02 \mathrm{mg} \cdot \mathrm{g}^{-1}$, and the soil $\mathrm{pH}$ was $4.05 \pm 0.02$ at $0-20 \mathrm{~cm}$ soil layer before burning treatment in all plots. The soil bulk density at the top $0-10 \mathrm{~cm}$ soil layer was not affected by prescribed burning in these studied plots (Wang et al. 2013).

\section{Plant biomass survey}

In July 2005, a permanent quadrat plot of $900 \mathrm{~m}^{2}$ (30 $\mathrm{m} \times 30 \mathrm{~m}$ ) was established in each of three replicates for the E. urophylla plantation (EU) and the naturally recovered shrubland (NS). Vegetation inventories were carried out in the 1st, 3rd, 4th and 6th year, respectively. The 
height $(H)$ and diameter $(D)$ at breast height for trees, and $H$ and basal diameter for shrubs $(D)$ were measured for each inventory. Allometric eqs. $\left(Y=a \times\left(D^{2} \times H\right)^{b}\right.$, where $a$ and $b$ are statistic parameters; $H$ and $D$ are the height and diameter at breast height for trees, and height and basal diameter for shrubs) based on the $H$ and $D$ were applied to calculate biomass of trees and shrubs in each treatment (Chen et al. 2015).

Biomass of herbs and forest floor mass (dead plant materials on soil surface) were estimated by harvest method only in the 6th year for multiple reasons. To avoid destroying the permanent quadrat plots, three $1 \mathrm{~m} \times 1 \mathrm{~m}$ subplots around only the quadrat were selected randomly and all above- and below-ground biomass of herbs, and forest floors in the subplots were harvested as separate samples. All samples were taken back to the laboratory and then were dried in an air-oven at $65^{\circ} \mathrm{C}$ to obtain constant weights for the estimation of biomass. $\mathrm{C}$ concentrations of herb and forest floor samples were analyzed by the traditional potassium dichromate oxidation method (Lu 1999).

Tree and shrub biomass $C$ storage per unit area were calculated as follows: tree/shrub biomass per unit area $\times$ 0.5 (assuming a constant $\mathrm{C}$ concentration of $50 \%$ ). Herb biomass $\mathrm{C}$ storage and forest floor mass $\mathrm{C}$ storage per unit area were calculated as following: herb biomass/forest floor mass per unit area $\times$ measured $C$ concentration.

\section{Soil sample collection and analysis}

Surface soil samples were collected in the 6th year after treatments. The soils were sampled with a corer $(3.0 \mathrm{~cm}$ in diameter) at $0-10 \mathrm{~cm}$ and at $10-20 \mathrm{~cm}$ depths from nine randomly selected microsites in each quadrat. Three cores at the same depth from the same slope positions were combined to yield one pooled sample, and three pooled samples were collected for each quadrat plot. Visible plant residues and roots were removed by hand. Then, the soil samples were sieved by a 2-mm mesh screen for soil physicochemical property analysis. SOC concentration was determined by the traditional potassium dichromate oxidation method (Lu 1999). SOC storage at a specific depth in a given area was calculated as

$$
\mathrm{SOCS}=\mathrm{SOC} \times \mathrm{TH} \times \mathrm{BD} \times(1-\mathrm{PF}) / 10
$$

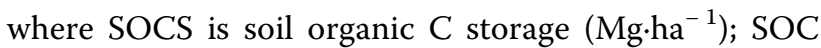
is the soil organic $\mathrm{C}$ concentration $\left(\mathrm{g} \cdot \mathrm{kg}^{-1}\right)$; $\mathrm{TH}$ is the thickness of the soil horizon $(\mathrm{cm})$; $\mathrm{BD}$ is the bulk density $\left(\mathrm{g} \cdot \mathrm{cm}^{-3}\right)$; and PF is the mass percentage of fragments, sand and stone $(>2 \mathrm{~mm})$. Soil bulk density for soil samples from both the $0-10$ and $10-20 \mathrm{~cm}$ layers was determined using a steel ring sampler of $100 \mathrm{~cm}^{3}$ volume $(5 \mathrm{~cm}$ diameter). Soil bulk density was calculated by dividing the weight of the dried soil by the volume of the soil (Guo et al. 2016).

\section{Data analysis}

Tree and shrub biomass $\mathrm{C}$ storage were analyzed by repeated-measures ANOVA, with burning as the between-subject factor and stand age as the within-subject factor. One-way ANOVA was employed to test the effects of burning on biomass $\mathrm{C}$ storage of tree and shrub at the same stand age, herb biomass $C$ storage, forest floor $C$ storage and SOC storage in the E. urophylla plantation and the naturally recovered shrubland. Two-way ANOVA was performed to reveal the effects of burning and vegetation types on plant biomass C storage, SOC storage, ecosystem C storage, and soil bulk density. Pearson correlation analyses were conducted in order to determine the relationship between plant biomass $\mathrm{C}$ storage and SOC storage. When required to meet the assumptions of normality and homogeneity of variance, data were reciprocally or square-root transformed. Statistical significance was determined at $P<0.05$. All these analyses were performed using SPSS software (IBM, Chicago, USA).

\section{Results}

Tree biomass $\mathrm{C}$ storage

Repeated-measures ANOVA indicated that prescribed burning did not show any significant effect on tree biomass $\mathrm{C}$ storage in the EU and NS (Fig. 1a and b). While, tree biomass $\mathrm{C}$ storage in the $\mathrm{BEU}$ was $83.63 \%, 7.10 \%$, $20.99 \%$ and $20.63 \%$ higher than in the UEU at $1,3,4$ and 6 years of age, respectively, and the difference was significant at 1 year of age and not at 3, 4 and 6 years of age. At 1 year of age, tree biomass $\mathrm{C}$ storage in the $\mathrm{BEU}(7.18 \mathrm{Mg}$ $\left.\mathrm{C} \cdot \mathrm{ha}^{-1}\right)$ was higher than in the UEU $\left(3.91 \mathrm{Mg} \mathrm{C} \cdot \mathrm{ha}^{-1}\right)(F$ $=26.87, P=0.007$; Fig. 1a). By contrast, tree biomass $\mathrm{C}$ storage in the BNS was $12.07 \%, 74.67 \%, 60.92 \%$ and 99.21\% lower than in the UNS at 1, 3, 4, and 6 years of age, although the differences were not significant (all $P>$ 0.178; Fig. 1b). In addition, two-way ANOVA showed that vegetation types significantly affected tree biomass $\mathrm{C}$ storage at 6 years of age (Table 1), and tree biomass $C$ storage was significantly higher in the EU than that in the NS. But the burning did not significantly affect tree biomass $\mathrm{C}$ storage. Meanwhile, the interaction effect of vegetation types and burning was not significant (Table 1).

\section{Shrub biomass $C$ storage}

Shrub biomass C storage was 0.16 to 0.92 and 0.29 to $0.91 \mathrm{Mg} \mathrm{C} \cdot \mathrm{ha}^{-1}$ from 1 to 6 years of age for the EU and NS, respectively. Repeated-measures ANOVA showed that the effect of burning on shrub biomass $\mathrm{C}$ storage was not significant in the EU (Fig. 1c) or in the NS (Fig. 1d). Interestingly, shrub biomass $C$ storage was slightly higher both in the BEU than in the UEU and in the BNS than in the UNS at $1,3,4$, and 6 years of age, although the differences were not significant (all $P>0.211$ ). Two-way ANOVA indicated that neither vegetation 

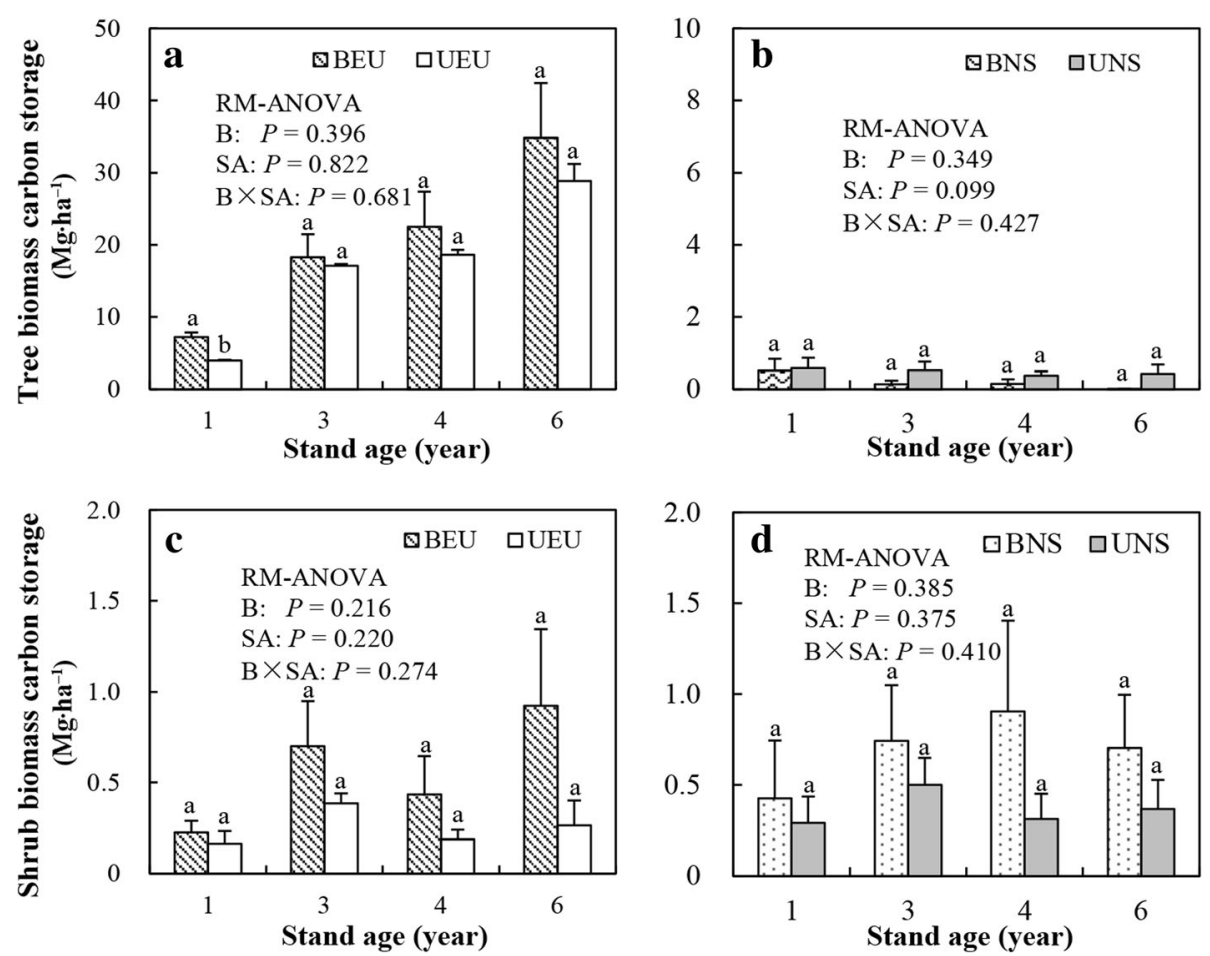

Fig. 1 Tree biomass carbon storage $(\mathbf{a}, \mathbf{b})$ and shrub biomass carbon storage $(\mathbf{c}, \mathbf{d})$ in the 1st year to 6th year after treatments, respectively, corresponding to 2006 to 2011. BEU, UEU, BNS and UNS refers to the burned Eucalyptus plantation, unburned Eucalyptus plantation, burned naturally recovered shrubland and unburned naturally recovered shrubland, respectively. Values are means $+\mathrm{SE}, n=3$. Lowercase letters indicate significant differences in tree/ shrub biomass carbon storage between burned and unburned treatments in the Eucalyptus plantation or naturally recovered shrubland at the same stand age at the $P=0.05$ level. B: burning; SA: stand age. The inserted P-values were from repeated measures ANOVA

types nor burning significantly affected shrub biomass $\mathrm{C}$ storage at 6 years of age, and the interaction effect of vegetation types and burning was not significant (Table 1).

\section{Herb biomass C storage}

Two-way ANOVA showed that both the prescribed burning and vegetation types significantly affected herb biomass $\mathrm{C}$ storage (Table 1). Vegetation types caused a different response of herb biomass $C$ storage to prescribed burning. In the EU, prescribed burning did not significantly affect herb biomass $C$ storage $(F=1.04, P=0.365)$, which was $12.92 \%$ lower in the $\mathrm{BEU}\left(7.50 \mathrm{Mg} \mathrm{C} \cdot \mathrm{ha}^{-1}\right)$ than in the UEU (8.62 Mg C.ha ${ }^{-1}$ ) (Fig. 2). Whereas herb biomass $C$ storage was $67.19 \%$ higher in the BNS (12.77

Table 1 Effects of burning (B), vegetation types (VT) and their interaction effects on C storage in tree biomass, shrub biomass, herb biomass, total plant biomass (the sum of tree, shrub and herb biomasses), forest floors, and soil organic C (SOC) storage at 0-20 cm depth, ecosystem $C$ storage (the sum of tree biomass $C$, shrub biomass $C$, herb biomass $C$, forest floors $C$ and SOC), and soil bulk density in the 6th year after treatments

\begin{tabular}{|c|c|c|c|c|c|c|}
\hline \multirow[t]{2}{*}{ Factors } & \multicolumn{2}{|l|}{ B } & \multicolumn{2}{|l|}{ VT } & \multicolumn{2}{|l|}{$\mathrm{B} \times \mathrm{VT}$} \\
\hline & $\bar{F}$ & $P$ & $F$ & $P$ & $\bar{F}$ & $P$ \\
\hline Tree biomass $C$ & 0.48 & 0.508 & 62.60 & 0.000 & 0.64 & 0.449 \\
\hline Shrub biomass $C$ & 3.19 & 0.112 & 0.05 & 0.826 & 0.35 & 0.573 \\
\hline Herb biomass $C$ & 8.50 & 0.019 & 9.69 & 0.014 & 20.51 & 0.002 \\
\hline Total plant biomass C & 1.48 & 0.259 & 46.24 & $<0.001$ & $<0.01$ & 0.961 \\
\hline Forest floors $C$ & 2.80 & 0.133 & 6.38 & 0.035 & 0.34 & 0.574 \\
\hline SOC storage & 0.00 & 0.968 & 0.07 & 0.799 & 1.14 & 0.316 \\
\hline Ecosystem C & 0.23 & 0.642 & 12.08 & 0.008 & 0.28 & 0.608 \\
\hline Soil bulk density $(0-10 \mathrm{~cm})$ & 1.88 & 0.208 & 0.04 & 0.842 & 0.47 & 0.512 \\
\hline Soil bulk density $(10-20 \mathrm{~cm})$ & 0.37 & 0.560 & 1.24 & 0.298 & 1.73 & 0.224 \\
\hline
\end{tabular}




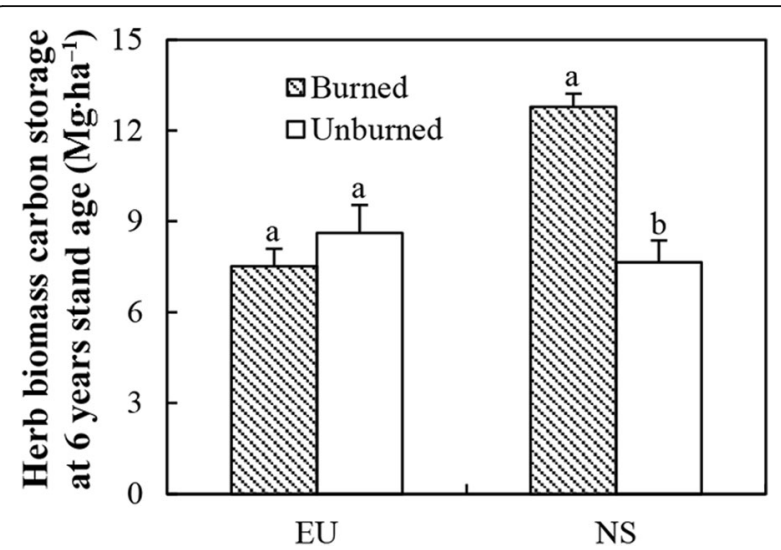

Fig. 2 Herb biomass carbon storage in the 6th year (2011) after treatments. EU and NS refers to the Eucalyptus plantation, and naturally recovered shrubland, respectively. Values are means $+\mathrm{SE}, n=3$. Lowercase letters indicate significant differences in herb biomass carbon storage between burned and unburned treatment in the same vegetation type at the $P=0.05$ level

$\left.\mathrm{Mg} \mathrm{C} \cdot \mathrm{ha}^{-1}\right)$ than in the UNS $\left(7.64 \mathrm{Mg} \mathrm{C} \cdot \mathrm{ha}^{-1}\right)$, and the difference was significant $(F=37.08, P=0.004$; Fig. 2$)$. The interaction effect of vegetation types and burning on herb biomass $C$ storage was significant (Table 1 ).

\section{Forest floor C storage}

Two-way ANOVA suggested that vegetation types significantly affected forest floor C storage (Table 1). Forest floor $\mathrm{C}$ storage was significantly higher in the EU than in the NS (Table 2). However, burning did not significantly affect forest floor $\mathrm{C}$ storage. And the interaction effect of vegetation types and burning on forest floor $\mathrm{C}$ storage was not significant (Table 1). One-way ANOVA showed that forest floor $\mathrm{C}$ storage in the BEU was lower $16.16 \%$ than in the UEU, although the difference was not significant (Table 2). In the NS, burning significantly affected forest floor $\mathrm{C}$ storage, which was $77.10 \%$ lower in the BNS than in the UNS (Table 2).

\section{SOC storage}

Prescribed burning did not significantly affect SOC storage in the EU or in the NS either at the $0-10 \mathrm{~cm}$ or at the $10-20 \mathrm{~cm}$ soil layers (Table 2). In the $0-20 \mathrm{~cm}$ soil layer, SOC storages were 30.48, 35.80, 34.66 and 28.91 $\mathrm{Mg} \mathrm{C} \cdot \mathrm{ha}^{-1}$ for the BEU, UEU, BNS and UNS, respectively (Table 2). In addition, two-way ANOVA showed that neither vegetation types nor prescribed burning significantly affected SOC storage, and the interaction effect of vegetation types and burning on SOC storage was not significant at the $0-20 \mathrm{~cm}$ soil layer (Table 1 ).

\section{Ecosystem C storage in the 6th year}

In this study, total plant biomass $C$ storage was the sum of tree, shrub, and herb biomass $C$ storage. Ecosystem $C$ storage was the sum of total plant biomass $\mathrm{C}$, forest floor C, and SOC storage at the $0-20 \mathrm{~cm}$ layer. The total plant biomass $C$ storage were 43.21, 37.72, 13.48 and $8.43 \mathrm{Mg} \mathrm{C} \cdot \mathrm{ha}^{-1}$ for the BEU, UEU, BNS and UNS, respectively (Table 2). Two-way ANOVA showed that burning did not significant affect total plant biomass $\mathrm{C}$ storage, yet vegetation types did significantly affect total plant biomass $\mathrm{C}$ storage. There was a significantly higher total plant biomass $C$ storage in the EU than in the NS. In addition, total plant biomass C storage was $14.56 \%$ and $59.93 \%$ higher when burning was present in the EU and NS, respectively, while the significant difference was observed only in the NS (Table 2).

Two-way ANOVA indicated that prescribed burning did not significantly affect ecosystem $C$ storage, yet the vegetation types did (Table 1). Ecosystem $C$ storage was higher in the EU than in the NS (Table 2). One-way ANOVA suggested that there was no significant difference in ecosystem C storage both between in the BEU (77.02 $\left.\mathrm{Mg} \mathrm{C} \mathrm{ha}^{-1}\right)$ and UEU (77.49 Mg C.ha $\left.{ }^{-1}\right)$, and between in the BNS (49.62 $\mathrm{Mg} \mathrm{C} \cdot \mathrm{ha}^{-1}$ ) and UNS (40.16 Mg C.ha $\left.{ }^{-1}\right)$, although it was 23.56\% higher in the BNS than in the UNS (Table 2).

Table 2 Total plant biomass $C$ storage (the sum of tree, shrub and herbs biomass $C$ storage), forest floors $C$ storage, and soil organic C (SOC) storage at the different depths as well as ecosystem $C$ storage (the sum of total plant biomass $C$, forest floors $C$, and SOC storage) in the 6th year after treatments. $P$ and $F$ values were from the results of one-way ANOVA. EU, NS, UB, B stand for Eucalyptus plantation, naturally recovered shrubland, and the treatments of unburning and burning, respectively

\begin{tabular}{|c|c|c|c|c|c|c|}
\hline \multirow{2}{*}{$\begin{array}{l}\text { C storage (Mg } \\
\mathrm{C} \cdot \mathrm{ha}^{-1} \text { ) }\end{array}$} & \multicolumn{3}{|l|}{ EU } & \multicolumn{3}{|l|}{ NS } \\
\hline & UB & $B$ & $P(F)$ & UB & B & $P(F)$ \\
\hline Total plant biomass & $37.72 \pm 2.81$ & $43.21 \pm 8.11$ & $0.557(0.41)$ & $8.43 \pm 1.04$ & $13.48 \pm 0.73$ & $0.017(15.74)$ \\
\hline Forest floor & $3.98 \pm 0.54$ & $3.33 \pm 0.95$ & $0.585(0.35)$ & $2.82 \pm 0.30$ & $1.48 \pm 0.36$ & $0.046(8.11)$ \\
\hline $\mathrm{SOC}(0-10 \mathrm{~cm})$ & $23.32 \pm 2.52$ & $20.13 \pm 5.89$ & $0.676(0.20)$ & $19.49 \pm 4.73$ & $22.50 \pm 2.08$ & $0.369(1.02)$ \\
\hline SOC $(10-20 \mathrm{~cm})$ & $12.48 \pm 0.60$ & $10.05 \pm 3.06$ & $0.479(0.61)$ & $9.42 \pm 1.96$ & $12.15 \pm 0.23$ & $0.239(1.91)$ \\
\hline $\mathrm{SOC}(0-20 \mathrm{~cm})$ & $35.80 \pm 2.96$ & $30.48 \pm 8.90$ & $0.601(0.32)$ & $28.91 \pm 4.11$ & $34.65 \pm 1.44$ & $0.258(1.74)$ \\
\hline Ecosystem & $77.49 \pm 4.23$ & $77.02 \pm 17.56$ & $0.980(0.00)$ & $40.16 \pm 4.26$ & $49.62 \pm 1.54$ & $0.105(4.36)$ \\
\hline
\end{tabular}




\section{Soil bulk density}

Two-way ANOVA indicated that neither prescribed burning nor vegetation types affected soil bulk density at the $0-10$ and $10-20 \mathrm{~cm}$ soil layers. Meanwhile, the interaction effects of prescribed burning and vegetation types on soil bulk density were not significant (Table 1).

\section{The correlations of vegetation C storage and SOC storage} Pearson correlation analyses showed that the tree biomass $\mathrm{C}$ storage was significantly and positively correlated to the forest floor $C$ storage, total plant biomass $C$ storage, and ecosystem $C$ storage $(P=0.020,<0.001$ and $<0.001$, respectively; Table 3 ), yet the herb biomass $C$ storage was negatively correlated to forest floor $C$ storage $(P=0.039)$. The significantly positive correlations between forest floor $\mathrm{C}$ storage and total plant biomass $\mathrm{C}$ storage was also be found $(P=0.035)$. Meanwhile, there were significantly positive correlations between forest floor $\mathrm{C}$ storage, total plant biomass $\mathrm{C}$ storage, SOC storage and ecosystem $C$ storage $(P=0.025,<0.001$ and 0.019 , respectively; Table 3 ).

\section{Discussion}

Effects of prescribed burning on plant biomass $\mathrm{C}$ storage Plant biomass $\mathrm{C}$ storage was influenced by prescribed burning. In the naturally recovered shrubland, the effect could be ascribed to the difference in herb biomass $\mathrm{C}$ storage in that the plant communities were dominated by herbs. In the Eucalyptus plantation, tree biomass $\mathrm{C}$ storage contributed a large proportion of plant biomass $\mathrm{C}$ storage.

Prescribed burning significantly increased tree biomass C storage in the 1st year in the Eucalyptus plantation; however, the effect was gradually weakened with increasing stand age. We speculated that prescribed burning accelerated nutrient return from residues (e.g., logging plant residues) on the soil surface shortly after burning, which promoted plant growth. Butler et al. (2017) found that prescribed burning increased the availability of soil phosphorus. Hence, prescribed burning enhanced tree

Table 3 The Pearson correlations ( $r$ ) between biomass $C$ storage of tree, shrub, herb, forest floor, total plant and soil organic C storage.

\begin{tabular}{llllllll}
\hline & Tree & Shrub & Herb & Forest floor & Plant & SOC & EC \\
\hline Tree & - & 0.215 & -0.493 & $0.657^{*}$ & $0.99^{* *}$ & 0.291 & $0.906^{* *}$ \\
Shrub & - & - & 0.029 & -0.267 & 0.262 & 0.186 & 0.254 \\
Herb & - & - & - & $-0.600^{*}$ & -0.374 & 0.140 & -0.269 \\
Forest floor & - & - & - & - & $0.610^{*}$ & 0.302 & $0.639^{*}$ \\
Plant & - & - & - & - & - & 0.356 & $0.935^{* *}$ \\
SOC & - & - & - & - & - & - & $0.662^{*}$
\end{tabular}

Note: Tree, shrub, herb, forest floor, plant, SOC, and EC stand for the C storage of tree biomass, shrub biomass, herb biomass, forest floor, and total plant biomass; soil organic carbon storage, and ecosystem carbon storage; respectively. *indicates $P<0.05,{ }^{* *}$ indicates $P<0.01$ and shrub biomass $\mathrm{C}$ storage. However, after a period of time, the nutrients derived from the decomposition of residues and litter in unburned plots with abundant logging residues could become richer than those in burned plots. As a result, the effect of prescribed burning on tree biomass in the Eucalyptus plantation was gradually weakened. In addition, the decreased soil $\mathrm{N}$ and soil available $\mathrm{P}$ in the burned Eucalyptus plantation after 3 years of treatments could be responsible for that (Sun et al. 2011). Furthermore, it could be ascribed to the physiological trait of Eucalyptus. The biomass of fast-growing Eucalyptus increased fast as the nutrients were relatively abundant at the early stage. That prescribed burning increased tree biomass $\mathrm{C}$ storage to some extent in Eucalyptus plantations in the present study was consistent with that observed in Chinese fir plantations by Zhou et al. (2016).

The herbs in the studied vegetation types were dominated by $D$. dichotoma. $D$. dichotoma is a light-demanding heliophyte and has a high light compensation point (Chen et al. 2016; Zhu et al. 2016) that is intensively controlled by canopy cover. In the Eucalyptus plantation, less biomass of $D$. dichotoma was found for the greater tree biomass. This result was supported by the results of Bataineh et al. (2006). Nevertheless, in the naturally recovered shrubland, plants were dominated by herbs such as $D$. dichotoma. Meanwhile, prescribed burning has been shown to accelerate nutrient return from residues on the soil surface, which promoted plant growth (Carter and Foster 2004; Close et al. 2011; Gautam and Mandal 2016). Furthermore, the litter of $D$. dichotoma decomposed slowly (Ma et al. 2009), and nutrient return from the litter of $D$. dichotoma was also slow. In addition, prescribed burning did not affect the germination of $D$. dichotoma. As a result, the herb biomass $\mathrm{C}$ storage in the BNS was higher than that in the UNS.

Forest floor $\mathrm{C}$ storage was significantly affected by prescribed burning in the naturally recovered shrubland. In the Eucalyptus plantation, forest floor $\mathrm{C}$ storage was also higher in unburned plots than in burned plots, yet not significantly. The observed forest floor $\mathrm{C}$ storage was not consistent with that reported by Kim et al. (2016). The following two possible reasons could be responsible for this difference. On the one hand, the pre-fire residues could be mixed on the forest floor and have a slow decomposition rate (Jiang et al. 2012). On the other hand, prescribed burning reduced the occurrence of diseased plants and insect pests (Houdeshell et al. 2011; Hall et al. 2016), so the litter production could be reduced. Although burning decreased the litter decomposition rate by shifting soil microbial communities (Sun et al. 2011; Holden et al. 2013), some of the soil microbial parameters changes (e.g., soil microbial biomass $\mathrm{C}, \mathrm{B}$-glucosidase, and phosphatase activities) were ephemeral, and only some of these changes lasted for 3 years (Fontúrbel et al. 2016). The intensity of 
prescribed burning could be responsible for these changes. Espinosa et al. (2018) found that litter productivity showed no significant difference 1 year after low intensity prescribed burning. In addition, great total plant biomass could produce more forest litter, it was supported by the positive relations between forest floor biomass $\mathrm{C}$ and total plant biomass $\mathrm{C}$ storage in this study.

\section{Effects of prescribed burning on SOC storage}

Prescribed burning did not affect SOC storage in the 0-10 and $10-20 \mathrm{~cm}$ soil layers in both the Eucalyptus plantation and naturally recovered shrubland. The observed SOC storage was consistent with previous studies (Neill et al. 2007; Roaldson et al. 2014). However, Rau et al. (2009) found that burning increased $\mathrm{C}$ and $\mathrm{N}$ within the first $0-3 \mathrm{~cm}$ of soil, and this change was not statistically detectable when integrated into the $0-8$ or $0-52 \mathrm{~cm}$ layers. In this study, the effect of prescribed burning on SOC was likely diluted in the $0-10 \mathrm{~cm}$ soil layer. Therefore, the soil thicknesses can have a dilution effect that is associated with the actual impacts of fire on soil properties (Armas-Herrera et al. 2016). Meanwhile, the season of prescribed burning could be responsible for this effect. Early season burns had less dramatic short-term effects on the soil abiotic conditions than late season burns (Hamman et al. 2008). In our study, the prescribed burning was conducted in March 2005. In addition, in this studied area, Sun et al. (2009) reported that SOC concentration in the $0-10 \mathrm{~cm}$ soil layer significantly decreased after 3 years of prescribed burning in Eucalyptus plantations, but we did not detect this effect after 6 years. This result suggested that the effect of prescribed burning on SOC could last for less than 6 years. Wang et al. (2016) found that prescribed burning changed the SOC release only in the 1st year. Additionally, the burning intensity drives the post-fire temporal pattern of SOC accumulation (Sawyer et al. 2018). Low- and moderate-intensity prescribed burning could have little effect on SOC storage on the long-term scale. Besides, the little effect of prescribed burning on SOC in the EU could be due to the nature of Eucalyptus, which is an exotic species with fast growth rate and could sequester more soil organic $\mathrm{C}$ as greater biomass $\mathrm{C}$ accumulation than native species. However, this was not supported by our previous result that the soil organic $\mathrm{C}$ accumulation was not significantly different between the plantations with fast-growing species (i.e. E. urophylla, and Acacia crassicarpa) and plantations with slow-growing species (Castanopsis hystrix, and a mixture of 10 native tree species) at the early development stages (Chen et al. 2017).

\section{Effects of prescribed burning and vegetation types on ecosystem C storage}

The ecosystem $\mathrm{C}$ storage was not affected by prescribed burning in both the Eucalyptus plantation and naturally recovered shrubland. The observed ecosystem $\mathrm{C}$ storage was consistent with that reported by others (Scheller et al. 2011). Santos et al. (2003) found that the negative effects of burning on the $\mathrm{C}$ balance of the ecosystem were more or less neutralized after only 12 months. Meanwhile, the effects of burning on $\mathrm{C}$ in ecosystems depended on the intensity of prescribed burning (Keeley 2009). However, the vegetation types had a significant effect on ecosystem $C$ storage as the difference in plant biomass $\mathrm{C}$ storage was mainly induced by plant traits (Chen et al. 2015). It was also supported by the significantly positive correlations between total plant biomass $C$ storage and ecosystem $C$ storage. The interaction effects of prescribed burning and vegetation types on herb biomass $C$ storage were apparent. Different plant species, vegetation types, and forest types could lead to various responses to burning (Prévosto et al. 2011; Balch et al. 2015; Lutz et al. 2017; Pellegrini et al. 2018). Therefore, the vegetation types should be considered when assessing the effects of prescribed burning on ecosystem $C$ dynamics.

There were several limitations in the present study. The SOC data were absent before the prescribed burning for the studied plots in spite of the similar site characteristics at the experimental sites, and the information on the SOC dynamics over time after treatments could not be evaluated. Besides, the effect of prescribed burning on forest $\mathrm{C}$ storage was only investigated in a Eucalyptus plantation and a naturally recovered shrubland, whether or not it can be applied to other forests needs more investigation.

\section{Conclusions}

In subtropical plantations, we found that prescribed burning significantly increased herb biomass $\mathrm{C}$ storage and total plant biomass $\mathrm{C}$ storage in the naturally recovered shrubland, and slightly increased tree biomass $\mathrm{C}$ storage and total plant biomass C storage in the Eucalyptus plantation. However, SOC storage and ecosystem C storage were not significantly affected by prescribed burning in two vegetation types. Consequently, we conclude that prescribed burning has little impact on overall C storage of forest ecosystems, and could be an option for forest site preparation in subtropics.

\section{Abbreviations \\ BEU: burned Eucalyptus urophylla plantation; BNS: burned naturally recovered shrubland; C: carbon; EU: Eucalyptus urophylla plantation; N: nitrogen; \\ NS: naturally recovered shrubland; SOC: soil organic carbon.; UEU: unburned Eucalyptus urophylla plantation; UNS: unburned naturally recovered shrubland \\ Acknowledgements \\ We are very grateful to all members of Heshan National Field Research Station of Forest Ecosystem, who helped setting up the quadrats and investigating vegetation.}

\section{Funding}

This study was funded by the National Natural Science Foundation of Major International (Regional) Joint Research Project of China (No. 31210103920), the Hunan Provincial Natural Science Foundation of China (No. 2017JJ3083), the Research Foundation of Education Bureau of Hunan Province, China (No. 17B099). 


\section{Availability of data and materials}

The datasets used and/or analyzed during the current study are available from the corresponding author on reasonable request.

\section{Authors' contributions}

SF and LZ designed and supervised the research. YC, JC and FL carried out the field and laboratory works. YC analyzed data and wrote the manuscript. SF improved the manuscript. All authors read and approved the final manuscript.

\section{Ethics approval and consent to participate}

Not applicable.

\section{Consent for publication}

Not applicable.

\section{Competing interests}

The authors declare that they have no competing interests.

\section{Author details}

'Hunan Province Key Laboratory of Coal Resources Clean-utilization and Mine Environment Protection, Hunan University of Science and Technology, Xiangtan 411201, China. ${ }^{2}$ Key Laboratory of Ecological Remediation and Safe Utilization of Heavy Metal-polluted Soils, College of Hunan Province, School of Life Science, Hunan University of Science and Technology, Xiangtan 411201, Hunan, China. ${ }^{3}$ Key Laboratory of Vegetation Restoration and Management of Degraded Ecosystems, South China Botanical Garden, Chinese Academy of Sciences, Guangzhou 510650, China. ${ }^{4}$ University of Chinese Academy of Sciences, Beijing 100049, China. ${ }^{5}$ Key laboratory of Geospatial Technology for the Middle \& Lower Yellow River Regions, Ministry of Education, College of Environment and Planning, Henan University, Kaifeng 475004, China.

\section{Received: 20 December 2018 Accepted: 18 April 2019} Published online: 13 May 2019

\section{References}

Alcañiz M, Outeiro L, Francos M, Farguell J, Úbeda X (2016) Long-term dynamics of soil chemical properties after a prescribed fire in a Mediterranean forest (Montgrí massif, Catalonia, Spain). Sci Total Environ 572:1329-1335

Alcañiz M, Outeiro L, Francos M, Úbeda X (2018) Effects of prescribed fires on soil properties: a review. Sci Total Environ 613:944-957

Armas-Herrera CM, Martí C, Badía D, Ortiz-Perpiñá O, Girona-García A, Porta J (2016) Immediate effects of prescribed burning in the Central Pyrenees on the amount and stability of topsoil organic matter. Catena 147:238-244

Balch JK, Brando PM, Nepstad DC, Coe MT, Silvério D, Massad TJ, Davidson EA, Lefebvre P, Oliveira-Santos C, Rocha W, Cury RT, Parsons A, Carvalho KS (2015) The susceptibility of southeastern Amazon forests to fire: insights from a large-scale burn experiment. Bioscience 65:893-905

Bataineh AL, Oswald BP, Bataineh MM, Williams HM, Coble DW (2006) Changes in understory vegetation of a ponderosa pine forest in northern Arizona 30 years after a wildfire. For Ecol Manag 235:283-294

Butler OM, Lewis T, Chen C (2017) Prescribed fire alters foliar stoichiometry and nutrient resorption in the understory of a subtropical eucalypt forest. Plant Soil 410:181-191

Carter MC, Foster CD (2004) Prescribed burning and productivity in southern pine forests: a review. For Ecol Manag 191:93-109

Certini $\mathrm{G}$ (2005) Effects of fire on properties of forest soils: a review. Oecologia 143:1-10

Chen Y, Liu Z, Rao X, Wang X, Liang C, Lin Y, Zhou L, Cai X, Fu S (2015) Carbon storage and allocation pattern in plant biomass among different forest plantation stands in Guangdong, China. Forests 6:794-808

Chen Y, Yu S, Liu S, Wang X, Zhang Y, Liu T, Zhou L, Zhang W, Fu S (2017) Reforestation makes a minor contribution to soil carbon accumulation in the short term: evidence from four subtropical plantations. For Ecol Manag 384:400-405

Chen Z, Chen Z, Yan X, Bai L (2016) Stoichiometric mechanisms of Dicranopteris dichotoma growth and resistance to nutrient limitation in the Zhuxi watershed in the red soil hilly region of China. Plant Soil 398:367-379

China Forestry Database.(n.d.) Statistic data of the 8th national forest resources continuous inventory. http://124.205.185.8/lysjk/indexJump.do?url=view/ moudle/dataQuery/dataQuery. Accessed 20 Mar 2018

China Science Daily (2015) International Union of Forestry Research Organization Eucalypt Conference 2015. China science Daily the, 4th edn section, 26 Oct 2015 (In Chinese)
Close DC, Davidson NJ, Swanborough PW, Corkrey R (2011) Does low-intensity surface fire increase water-and nutrient-availability to overstorey Eucalyptus gomphocephala? Plant Soil 349:203-214

Espinosa J, Madrigal J, De La Cruz AC, Guijarro M, Jimenez E, Hernando C (2018) Short-term effects of prescribed burning on litterfall biomass in mixed stands of Pinus nigra and Pinus pinaster and pure stands of Pinus nigra in the Cuenca Mountains (central-eastern Spain). Sci Total Environ 618:941-951

Fahey TJ, Woodbury PB, Battles JJ, Goodale CL, Hamburg SP, Ollinger SV, Woodall CW (2010) Forest carbon storage: ecology management and policy. Front Ecol Environ 8:245-252

Fischer M, Kelley AM, Ward EJ, Boone JD, Ashley EM, Domec JC, Williamson JS, King JS (2017) A critical analysis of species selection and high vs low-input silviculture on establishment success and early productivity of model shortrotation wood-energy cropping systems. Biomass Bioenergy 98:214-227

Fontúrbel MT, Fernández C, Vega JA (2016) Prescribed burning versus mechanical treatments as shrubland management options in NW Spain: mid-term soil microbial response. Appl Soil Ecol 107:334-346

Fultz LM, Moore-Kucera J, Dathe J, Davinic M, Perry G, Wester D, Schwilk DW, Rideout-Hanzak S (2016) Forest wildfire and grassland prescribed fire effects on soil biogeochemical processes and microbial communities: two case studies in the semi-arid southwest. Appl Soil Ecol 99:118-128

Gautam TP, Mandal TN (2016) Effect of disturbance on biomass, production and carbon dynamics in moist tropical forest of eastern Nepal. For Ecosyst 3:11

Glitzenstein JS, Streng DR, Masters RE, Robertson KM, Hermann SM (2012) Firefrequency effects on vegetation in North Florida pinelands: another look at the long-term Stoddard fire research plots at tall timbers research station. For Ecol Manag 264:197-209

Granged AJ, Jordán A, Zavala LM, Muñoz-Rojas M, Mataix-Solera J (2011) Shortterm effects of experimental fire for a soil under eucalyptus forest (SE Australia). Geoderma 167:125-134

Guo L, Wu G, Li Y, Li C, Liu W, Meng J, Liu H, Yu X, Jiang G (2016) Effects of cattle manure compost combined with chemical fertilizer on topsoil organic matter bulk density and earthworm activity in a wheat-maize rotation system in eastern China. Soil Tillage Res 156:140-147

Hall JV, Loboda TV, Giglio L, McCarty GW (2016) A MODIS-based burned area assessment for Russian croplands: mapping requirements and challenges. Remote Sens Environ 184:506-521

Hamman ST, Burke IC, Knapp EE (2008) Soil nutrients and microbial activity after early and late season prescribed burns in a Sierra Nevada mixed conifer forest. For Ecol Manag 256:367-374

Holden SR, Gutierrez A, Treseder KK (2013) Changes in soil fungal communities extracellular enzyme activities and litter decomposition across a fire chronosequence in Alaskan boreal forests. Ecosystems 16:34-46

Houdeshell H, Friedrich RL, Philpott SM (2011) Effects of prescribed burning on ant nesting ecology in oak savannas. Am Midl Nat 166:98-111

Hu H, Hu T, Sun L (2016) Spatial heterogeneity of soil respiration in a Larix gmelinii forest and the response to prescribed fire in the greater Xing'an mountains China. J For Res 27:1153-1162

Jiang X, Dou R, Yu S, Ma Y (2012) Leaf litter decomposition subtropical plants with different origin time in the south subtropical Asia. J Anhui Agric Sci 40: 12054-12058 (in Chinese with an English Abstract)

Keeley JE (2009) Fire intensity, fire severity and burn severity: a brief review and suggested usage. Int J Wildland Fire 18:116-126

Kim DG, Taddese H, Belay A, Kolka R (2016) The impact of traditional fire management on soil carbon and nitrogen pools in a montane forest southern Ethiopia. Int J Wildland Fire 25:1110-1116

Krishnaraj SJ, Baker TG, Polglase PJ, Volkova L, Weston CJ (2016) Prescribed fire increases pyrogenic carbon in litter and surface soil in lowland eucalyptus forests of South-Eastern Australia. For Ecol Manag 366:98-105

Landry JS, Matthews HD, Ramankutty N (2015) A global assessment of the carbon cycle and temperature responses to major changes in future fire regime. Clim Chang 133:179-192

Lu RK (1999) Method of analysis in soil and agrochemistry. Agricultural Press, Beijing, pp 31-33 (in Chinese)

Lutz JA, Matchett JR, Tarnay LW, Smith DF, Becker KM, Furniss TJ, Brooks ML. (2017) Fire and the distribution and uncertainty of carbon sequestered as aboveground tree biomass in Yosemite and Sequoia \& Kings Canyon National Parks. Land 6:10

Ma YD, Jiang H, Yu SQ, Dou RP, Guo PP, Wang B (2009) Leaf litter decomposition of plants with different origin time in the mid-subtropical China. Acta Ecol Sin 29:5237-5245 (in Chinese with an English Abstract) 
Marín-Spiotta E, Sharma S (2013) Carbon storage in successional and plantation forest soils: a tropical analysis. Glob Ecol Biogeogr 22:105-117

Muqaddas B, Chen C, Lewis T, Wild C (2016) Temporal dynamics of carbon and nitrogen in the surface soil and forest floor under different prescribed burning regimes. For Ecol Manag 382:110-119

Neill C, Patterson WA, Crary DW (2007) Responses of soil carbon nitrogen and cations to the frequency and seasonality of prescribed burning in a Cape Cod oak-pine forest. For Ecol Manag 250:234-243

North MP, Hurteau MD (2011) High-severity wildfire effects on carbon stocks and emissions in fuels treated and untreated forest. For Ecol Manag 261:1115-1120

Pellegrini AF, Ahlström A, Hobbie SE, Reich PB, Nieradzik LP, Staver AC, Scharenbroch BC, Jumpponen A, Anderegg WRL, Randerson JT, Jackson RB (2018) Fire frequency drives decadal changes in soil carbon and nitrogen and ecosystem productivity. Nature 553:194-198

Pellegrini AF, Hedin LO, Staver AC, Govender N (2015) Fire alters ecosystem carbon and nutrients but not plant nutrient stoichiometry or composition in tropical savanna. Ecology 96:1275-1285

Prévosto B, Bousquet-Mélou A, Ripert C, Fernandez C (2011) Effects of different site preparation treatments on species diversity composition and plant traits in Pinus halepensis woodlands. Plant Ecol 212:627-638

Quality and Technology Supervision of Hainan Province, China (2004) The technical specification on fast growing high yield and short rotation of eucalyptus plantation. DB46/T 32-2004 (in Chinese)

Rau BM, Johnson DW, Blank RR, Chambers JC (2009) Soil carbon and nitrogen in a Great Basin pinyon-juniper woodland: influence of vegetation burning and time. J Arid Environ 73:472-479

Roaldson LM, Johnson DW, Miller WW, Murphy JD, Walker RF, Stein CM, Glass DW, Blank RR (2014) Prescribed fire and timber harvesting effects on soil carbon and nitrogen in a pine forest. Soil Sci Soc Am J 78:S48-S57

Santos AJB, Silva GTDA, Miranda HS, Miranda AC, Lloyd J (2003) Effects of fire on surface carbon energy and water vapour fluxes over campo sujo savanna in Central Brazil. Funct Ecol 17:711-719

Sawyer R, Bradstock R, Bedward M, Morrison RJ (2018) Fire intensity drives postfire temporal pattern of soil carbon accumulation in Australian fire-prone forests. Sci Total Environ 610:1113-1124

Scharenbroch BC, Nix B, Jacobs KA, Bowles ML (2012) Two decades of lowseverity prescribed fire increases soil nutrient availability in a Midwestern USA oak (Quercus) forest. Geoderma 183:80-91

Scheller RM, Van Tuyl S, Clark KL, Hom J, La Puma I (2011) Carbon sequestration in the New Jersey pine barrens under different scenarios of fire management. Ecosystems 14:987

Shorohova E, Kapitsa E, Vanha-Majamaa I (2008) Decomposition of stumps in a chronosequence after clear-felling vs clear-felling with prescribed burning in a southern boreal forest in Finland. For Ecol Manag 255:3606-3612

State Forestry Bureau (2014) The eighth forest resources inventory main results (2009-2013). http://www.forestry.gov.cn/main/65/20140225/659670.html. Accessed 20 Mar 2018

Sun Y, Wu J, Shao Y, Zhou L, Mai B, Lin Y, Fu S (2011) Responses of soil microbial communities to prescribed burning in two paired vegetation sites in southern China. Ecol Res 26:669-677

Sun Y, Wu J, Zhou L, Lin Y, Fu S (2009) Change of soil nutrient contents after prescribed burning of forestland in Heshan. Chin J Appl Ecol 20:513-517 (in Chinese with English abstract)

Wang F, Li J, Zou B, Xu X, Li Z (2013) Effect of prescribed fire on soil properties and N transformation in two vegetation types in South China. Environ Manag 51:1164

Wang H, Liu S, Mo J, Wang J, Makeschin F, Wolff M (2010) Soil organic carbon stock and chemical composition in four plantations of indigenous tree species in subtropical China. Ecol Res 25:1071-1079

Wang J, Wang H, Fu X, Xu M, Wang Y (2016) Effects of site preparation treatments before afforestation on soil carbon release. For Ecol Manag 361:277-285

Williams RJ, Hallgren SW, Wilson GW (2012) Frequency of prescribed burning in an upland oak forest determines soil and litter properties and alters the soil microbial community. For Ecol Manag 265:241-247

Zhou H, Meng S, Liu Q (2016) Diameter growth biological rotation age and biomass of Chinese fir in burning and clearing site preparations in subtropical China. Forests 7:177

Zhu SD, Li RH, Song J, He PC, Liu H, Berninger F, Ye Q (2016) Different leaf costbenefit strategies of ferns distributed in contrasting light habitats of subtropical forests. Ann Bot 117:497-506

\section{Submit your manuscript to a SpringerOpen ${ }^{\circ}$ journal and benefit from:}

- Convenient online submission

- Rigorous peer review

- Open access: articles freely available online

High visibility within the field

- Retaining the copyright to your article

Submit your next manuscript at $>$ springeropen.com 